\title{
JURNAL
}

\section{PENGARUH GAYA KEPEMIMPINAN TRANSAKSIONAL DAN \\ TRANSFORMASIONAL, MOTIVASI SERTA KOMPETENSI \\ TERHADAP KINERJA KARYAWAN PT. SANJAYATAMA LESTARI}

\author{
Jublina Oktora ${ }^{1}$, Mohamad Rizan ${ }^{2}$, Sihol Situngkir ${ }^{3}$ \\ Magister Manajemen Fakultas Ekonomi Universitas Negeri Jakarta \\ Email: jublinaoktora86@gmail.com,mohamadrizan72@gmail.com, \\ sihol_situngkir@yahoo.co.id
}

\footnotetext{
${ }^{1}$ mahasiswa

${ }^{23}$ dosen pembimbing
}

\begin{abstract}
Abstrak: Dalam penelitian ini tujuannya adalah untuk melakukan pengujian secara sistematis Pengaruh Gaya Kepemimpinan Transaksional Dan Transformasional, Motivasi Serta Kompetensi Terhadap Kinerja Karyawan PT. Sanjayatama Lestari. Sampel yang digunakan adalah karyawan PT. Sanjayatama Lestari dengan jumlah responden sebanyak 95 orang. Analisis yang digunakan adalah regresi linear berganda. Penelitian ini menguji 5 variabel yaitu Gaya Kepemimpinan Transaksional $\left(\mathrm{X}_{1}\right)$, Gaya Kepemimpinan Transformasional $\left(\mathrm{X}_{2}\right)$, Motivasi $\left(\mathrm{X}_{3}\right)$ dan Kompetensi $\left(\mathrm{X}_{4}\right)$ sebagai variabel bebas dan kinerja (Y) sebagai variabel terikat. Pengujian secara parsial menunjukkan bahwa gaya kepemimpinan transaksional berpengaruh sebesar 3,876 (positif dan signifikan) terhadap kinerja. Gaya kepemimpinan transformasional juga berpengaruh secara signifikan sebesar 3,128. Selanjutnya, motivasi juga mempunyai pengaruh secara signifikan sebesar 4,210 dan yang terakhir yaitu kompetensi berpengaruh secara signifikan sebesar 6,283.
\end{abstract}

Kata Kunci: Gaya kepemimpinan transaksional, gaya kepemimpinan transformasional, motivasi, kompetensi, kinerja dan regresi linear berganda. 


\section{LATAR BELAKANG}

Kinerja karyawan merupakan faktor utama dalam menentukan keberhasilan pencapaian suatu organisasi. Kinerja merupakan suatu fungsi dari motivasi dan kemampuan untuk menyelesaikan tugas atau pekerjaan. Seseorang sepatutnya memiliki derajat kesediaan dan tingkat kemampuan tertentu. Kesediaan dan keterampilan seseorang tidaklah cukup efektif untuk mengerjakan sesuatu tanpa pemahaman yang jelas tentang apa yang akan dikerjakan dan bagaimana mengerjakan. Kinerja merupakan perilaku nyata yang ditampilkan setiap orang sebagai pestasi kerja yang dihasilkan oleh karyawan sesuai dengan perannya dalam organisasi. Kinerja karyawan merupakan suatu hal yang sangat penting dalam upaya organisasi untuk mencapai tujuan. Organisasi umumnya mendasarkan perencanaan tujuan yang hendak dicapai di masa depan dengan perilaku yang diharapkan dari keseluruhan personel dalam mewujudkan tujuan tersebut.

Pengelolaan sumber daya manusia tidak terlepas dari faktor karyawan yang diharapkan dapat berprestasi sebaik mungkin demi mencapai tujuan suatu organisasi. Karyawan merupakan aset utama organisasi dan mempunyai peran yang strategis di dalam organisasi yaitu sebagai pemikir, perencana dan pengendali aktifitas organisasi.

Demi tercapainya tujuan organisasi, karyawan memerlukan motivasi untuk menghasilkan pekerja yang lebih baik. Melihat pentingnya karyawan dalam suatu organisasi, maka setiap karyawan diperlukan perhatian lebih serius terhadap tugas yang dikerjakan sehingga tujuan organisasi tercapai.

Pada tahun 2012, kinerja karyawan PT Sanjayatama Lestari dinilai sangatlah baik karena hal itu tampak terlihat jelas melalui kinerja karyawan PT. Sanjayatama Lestari yang optimal. Melalui gaya kepemimpinan Ibunda sebagai Direktur, para karyawan merasa senang dan nyaman, hal ini terlihat jelas bahwa tidak ada satupun karyawan yang meminta untuk berhenti dan keluar dari tempatnya bekerja. Karyawan juga bekerja secara optimal dan tidak pernah terlambat datang ke kantor karena mereka selalu berusaha untuk bertanggungjawab atas pekerjaannya. Namun semenjak tahun 2013 jabatan 
Direktur diambil alih oleh anak tirinya, banyak penurunan yang terjadi di perusahaan. Penurunan kinerja karyawan terlihat melalui data penjualan produk sabun cair di wilayah DKI Jakarta, sebagai berikut:

Tabel 1

Rekapitulasi Data Penjualan Produk PT. Sanjayatama Lestari

\begin{tabular}{|c|l|c|c|}
\hline No & \multicolumn{1}{|c|}{ Nama Produk } & 2012 & 2013 \\
\hline 1 & Lux & $41,44 \%$ & $35,12 \%$ \\
\hline 2 & Lifebuoy & $32,13 \%$ & $25,16 \%$ \\
\hline 3 & Dove & $4,15 \%$ & $1,78 \%$ \\
\hline
\end{tabular}

Sumber: Data diolah PT. Sanjayatama Lestari

Pada Tabel 1 di tahun 2012 penjualan produk sabun cair di wilayah DKI Jakarta dinilai baik oleh perusahaan, namun pada tahun 2013 penjualan produk sabun cair mengalami penurunan. Penjualan produk Lux dari 41,44\% turun menjadi $35,12 \%$, penjualan produk Lifebuoy dari $32,13 \%$ turun menjadi $25,16 \%$ begitu juga dengan penjualan produk Dove dari 4,15\% turun menjadi 1,78\%. Saat ibunda menjabat sebagai Direktur, beliau sering memberikan motivasi untuk bekerja keras memajukan PT. Sanjayatama Lestari dan menjual produkproduknya agar melampaui target penjualan. Apabila melampaui target penjualan, maka karyawan tersebut akan mendapatkan bonus yang didapat dari kantor maupun dari uang pibadi Ibunda.

Jika terjadi kecelakaan kerja maka Ibunda akan memberikan tambahan jaminan kesehatan melalui uang pribadinya, walaupun jaminan kesehatan sudah diberikan oleh kantor. Selain itu bonus tunjangan hari raya Lebaran juga diberikan kepada semua karyawannya dan bonus tunjangan hari raya Natal diberikan kepada umat Nasrani.

Oleh karena perhatian dan dukungan yang diberikan oleh ibunda maka kinerja karyawan pun dinilai baik bahkan sangat baik, berbeda saat jabatan direktur diambil alih oleh anak tirinya. Perhatian dan dukungan yang diberikan 
untuk karyawan dinilai sangatlah kurang. Oleh karena itu kinerja yang diberikan karyawan pun juga menjadi berkurang.

Selain itu banyak karyawan yang keluar dari PT. Sanjayatama Lestari. Di sini penulis melampirkan data tahun 2014 saja, yang digambarkan seperti pada tabel berikut ini:

Tabel 2

Rekapitulasi Karyawan PT. Sanjayatama Lestari Tahun 2014

\begin{tabular}{|c|c|c|}
\hline No & Bulan & Jumlah Karyawan Keluar \\
\hline 1 & Februari 2014 & 3 \\
\hline 2 & April 2014 & 5 \\
\hline 3 & Mei 2014 & 4 \\
\hline 4 & Juli 2014 & 3 \\
\hline 5 & September 2014 & 2 \\
\hline & Total & 17 Karyawan \\
\hline
\end{tabular}

Sumber: Data diolah PT. Sanjayatama Lestari, 2014

Berdasarkan data-data yang tercantum dalam Tabel 2 menunjukkan bahwa telah terjadi masalah berupa banyaknya karyawan yang keluar dari PT. Sanjayatama Lestari. Salah satu faktor yang memegang peranan utama adalah gaya kepemimpinan (leadership style). Karyawan tidak merasa puas dengan adanya keputusan-keputusan yang diberikan Direktur untuk para karyawannya. Karyawan menilai bahwa keputusan tersebut hanya menguntungkan pihak Direktur, oleh karena itu mereka memutuskan untuk keluar dari PT. Sanjayatama Lestari.

Motivasi yang diberikan oleh anak tirinya dianggap kurang maksimal bagi karyawan, karena bonus yang diberikan hanya berasal dari kantor, selain itu dihapuskannya bonus tunjangan hari raya Natal bagi umat Nasrani. Penurunan 
motivasi karyawan itu terlihat pada banyaknya jumlah karyawan yang terlambat. Disini penulis hanya melampirkan data tahun 2014 saja, yang digambarkan seperti pada tabel berikut ini:

Tabel 3

Rekapitulasi Karyawan PT. Sanjayatama Lestari Tahun 2014

\begin{tabular}{|c|c|c|c|c|}
\hline No & Bulan & $\begin{array}{c}\text { Jumlah } \\
\text { Karyawan }\end{array}$ & $\begin{array}{c}\text { Jumlah Karyawan Yang } \\
\text { Terlambat }\end{array}$ & Persentase \\
\hline 1 & Januari & 95 & 4 & $4,21 \%$ \\
\hline 2 & Februari & 95 & 3 & $3,15 \%$ \\
\hline 3 & Maret & 95 & 5 & $5,26 \%$ \\
\hline 4 & April & 95 & $6,31 \%$ & $4,21 \%$ \\
\hline 5 & Juli & 95 & 4 & $3,15 \%$ \\
\hline 6 & September & 95 & 3 & $2,10 \%$ \\
\hline 7 & Oktober & 95 & 27 Karyawan & \\
\hline & Total & & & \\
\hline
\end{tabular}

Sumber: Data diolah PT. Sanjayatama Lestari, 2014

Tabel 3 menunjukkan data karyawan yang datang terlambat masuk ke kantor. Karena PT. Sanjayatama Lestari sudah menggunakan fingerprint maka absensi karyawan dapat terlihat dengan jelas. Mereka yang datang terlambat adalah mereka yang berpikir untuk tidak keluar dari pekerjaan tersebut karena mereka sudah berumur dan ingin menghabiskan masa kerjanya di tempat itu saja, namun akhirnya mereka seperti mau tidak mau datang ke kantor.

Penurunan kompetensi karyawan juga terlihat pada ketidaksiapan karyawan yang ingin memasarkan dan menjual produknya, hal ini dikarenakan kurang 
maksimalnya pemberian pelatihan bagi karyawan. Pelatihan yang diberikan berupa soft skill dan selling skill yaitu:

Tabel 4

Rekapitulasi Data Pelatihan PT. Sanjayatama Lestari

\begin{tabular}{|l|c|c|}
\hline \multicolumn{1}{|c|}{ Nama pelatihan } & 2012 & 2013 \\
\hline $\begin{array}{l}\text { Soft skill berupa make up dan kelengkapannya sesuai } \\
\text { dengan SOP grooming }\end{array}$ & 6 kali & 2 kali \\
\hline $\begin{array}{l}\text { Selling skill berupa mengetahui target dan pencapaiannya } \\
\text { dan melakukan pencatatan di logbook }\end{array}$ & 8 kali & 4 kali \\
\hline
\end{tabular}

Sumber: Data diolah PT. Sanjayatama Lestari

Pada tahun 2012, pelatihan soft skill sebesar 6 kali dan di tahun 2013 mengalami penurunan pelatihan yakni menjadi 2 kali. Pada tahun 2013, pelatihan selling skill sebesar 8 kali dan di tahun 2013 mengalami penurunan menjadi 4 kali saja. Hal ini diakibatkan oleh Direktur pada tahun 2013 mengurangi anggaran biaya pelatihan bagi karyawan. Padahal pelatihan tersebut dibutuhkan untuk meningkatkan kompetensi karyawan untuk memasarkan dan menjual produk.

Oleh karena itu, hal ini menjadi bahan kajian ilmiah yang menarik, sehingga dalam penulisan tesis ini peneliti tertarik untuk membuktikan secara ilmiah mengenai pengaruh gaya kepemimpinan yang dibagi menjadi dua yaitu gaya kepemimpinan transaksional dan transformasional, motivasi serta kompetensi terhadap kinerja karyawan PT. Sanjayatama Lestari.

\section{KERANGKA TEORETIK}

\section{Pengaruh gaya kepemimpinan transaksional terhadap kinerja}

Pola hubungan yang dikembangkan kepemimpinan transaksional adalah berdasarkan suatu sistem timbal balik (transaksi) yang sangat menguntungkan (mutual system of reinforcement) yaitu pemimpin memahami kebutuhan dasar para pengikutnya dan pemimpin menemukan penyelesaian atas cara kerja dari 
para pengikutnya tersebut. Pemimpin transaksional merancang cara kerja sedemikian rupa yang disesuaikan dengan jenis dan jenjang jabatannya dan melakukan interaksi atau hubungan mutualis. Gaya kepemimpinan transaksional yang diterapkan oleh seorang pimpinan akan mendorong karyawannya bekerja lebih baik lagi, sehingga program atau sasaran yang telah ditetapkan oleh organisasi akan dapat dicapai. Kinerja karyawan pada dasarnya merupakan ukuran kesuksesan perhitungan hasil akhir atau tingkat pencapaian hasil, baik oleh individu maupun kelompok dalam suatu organisasi untuk mencapai tujuan yang telah ditentukan. Berdasarkan uraian di atas, dapat diduga bahwa gaya kepemimpinan transaksional memiliki pengaruh positif dan signifikan terhadap kinerja karyawan PT. Sanjayatama Lestari.

\section{Pengaruh gaya kepemimpinan transformasional terhadap kinerja}

Berhasil atau tidaknya sebuah perusahaan sangat ditentukan oleh kepemimpinan, karena pemimpin bertanggungjawab atas kegagalan pelaksanaan pekerjaan, sebaliknya kesuksesan dalam memimpin sebuah organisasi merupakan keberhasilan seseorang mempengaruhi orang lain untuk menggerakkan atau menjalankan visinya, selain itu adanya koordinasi atau kerjasama yang baik antara pimpinan dan bawahannya. Kepemimpinan mempunyai kaitan yang erat dengan motivasi karena keberhasilan seorang pemimpin dalam menggerakkan orang lain dalam mencapai tujuan yang telah ditetapkan sangat bergantung kepada kewibawaan, selain itu bagaimana menciptakan motivasi dalam diri setiap karyawan, kolega ataupun pimpinan itu sendiri. Gaya kepemimpinan transformasional merupakan kepemimpinan yang terkait dengan identifikasi diri yang kuat, penciptaan visi bersama untuk masa depan dan hubungan antara pemimpin dan pengikut berdasar pada suatu hal yang lebih daripada sekedar pemberian penghargaan agar patuh. Pemimpin transformasional mendefinisikan kebutuhan untuk perubahan, menciptakan visi baru, memobilisasi komitmen untuk menjalankan visi dan mentransformasi pengikut baik pada tingkat individual maupun tingkat organisasi. Berdasarkan uraian di atas, maka diduga 
variabel gaya kepemimpinan transformasional mempunyai pengaruh positif dan signifikan terhadap kinerja karyawan PT. Sanjayatama Lestari.

\section{Pengaruh motivasi terhadap kinerja}

Pemimpin mempunyai visi yang menarik untuk masa depan, menetapkan standar yang tinggi bagi para bawahan. Optimis dan antusiasme memberikan dorongan dan arti terhadap apa yang perlu dilakukan, sehingga pemimpin semacam ini akan memperbesar optimisme dan antusiasme bawahan serta memotivasi dan mengispirasi bawahannya untuk melebihi harapan motivasional melalui dukungan emosional dan daya tarik emosional. Praktisnya dapat saja berupa tugas atau pekerjaan yang betul-betul menantang serta memberikan peluang bagi karyawan untuk terlibat dalam suatu proses kreatif baik dalam hal memberikan usulan ataupun mengambil keputusan dalam pemecahan masalah, sehingga hal ini juga akan memberikan nilai tambah bagi mereka sendiri. Oleh karena itu motivasi diduga mempunyai pengaruh positif dan signifikan terhadap kinerja karyawan PT. Sanjayatama Lestari.

\section{Pengaruh kompetensi terhadap kinerja}

Keberhasilan suatu organisasi atau perusahaan dipengaruhi oleh sumber daya yang ada di dalam perusahaan tersebut. Sumber daya yang dimaksud dapat berupa sumber daya manusia (SDM), fasilitas, dana dan faktor-faktor eksternal keorganisasian. Sumber daya manusia sangat memiliki peran yang penting guna mencapai sasaran organisasi atau perusahaan. Dengan demikian fokus kompetensi adalah untuk memanfaatkan pengetahuan dan keterampilan kerja guna mencapai kinerja optimal, kemampuan untuk secara berani dan bertanggungjawab melakukan suatu perubahan bilamana diperlukan dan menjadi suatu tuntutan dengan perubahan yang terjadi. Oleh karena itu kompetensi karyawan sangatlah penting untuk diperhatikan. Dengan demikian kompetensi diduga mempunyai pengaruh positif dan signifikan terhadap kinerja karyawan PT. Sanjayatama Lestari. 


\section{Model Penelitian}

Berdasarkan latar belakang dan landasan teori di atas, maka model penelitian pada penelitian ini dapat digambarkan sebagai berikut:

Gambar 1

Kerangka Teoretik

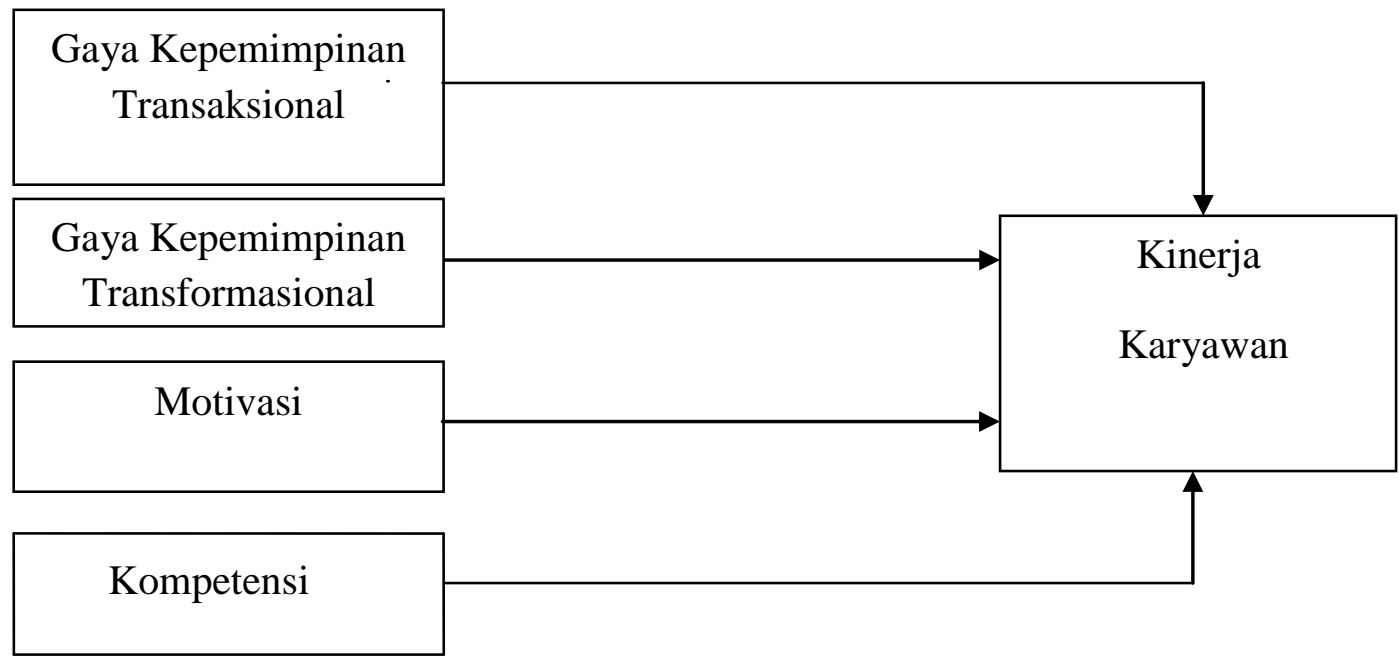

\section{Hipotesis Penelitian}

Berdasarkan hasil penelitian dan kerangka pemikiran di atas dapat dirumuskan hipotesis penelitian sebagai berikut:

1. $\mathrm{H} 1$ = Terdapat pengaruh yang signifikan antara gaya kepemimpinan transaksional terhadap kinerja karyawan.

2. $\mathrm{H} 2$ = Terdapat pengaruh yang signifikan antara gaya kepemimpinan transformasional terhadap kinerja karyawan.

3. $\mathrm{H} 3$ = Terdapat pengaruh yang signifikan antara motivasi terhadap kinerja karyawan.

4. $\mathrm{H} 4=$ Terdapat pengaruh yang signifikan antara kompetensi terhadap kinerja karyawan. 


\section{METODE PENELITIAN}

Metode penelitian yang digunakan adalah metode survey dan wawancara dengan pendekatan kausal menggunakan skala Likert. Instrumen penelitian yang digunakan berbentuk kuesioner. Penggunaan kuesioner untuk mendapatkan data dari setiap variabel penelitian. Dalam penelitian ini terdapat 5 (lima) variabel yang terdiri dari 4 (empat) variabel bebas yaitu gaya kepemimpinan transaksional, transformasional, motivasi serta kompetensi dan 1 (satu) variabel terikat yaitu kinerja karyawan.

\section{Sensus}

Dalam penelitian ini, target penelitian yang ingin diteliti yaitu para karyawan PT. Sanjayatama Lestari yang berjumlah 95 karyawan.

\section{HASIL}

Kuesioner yang disebar sejumlah 95 eksemplar dan karakteristik data dijelaskan sebagai berikut:

- Pada kategori jenis kelamin diketahui sebagian besar responden adalah berjenis kelamin perempuan sebanyak 60 responden (63\%), sedangkan responden laki-laki sebanyak 35 responden (37\%).

- Berdasarkan masa kerja 11 - 15 tahun sebanyak 35 responden (37\%), masa kerja 15 - 20 tahun sebanyak 25 responden (26\%), masa kerja 5 - 10 tahun sebanyak 20 responden (21\%) dan masa kerja kurang dari 5 tahun sebanyak 15 responden $(16 \%)$.

- Berdasarkan usia 31 - 35 tahun sebanyak 30 responden (31\%), usia $36-40$ tahun sebanyak 18 responden (19\%). Usia 26 - 30 tahun sebanyak 17 responden (18\%) dan usia kurang dari 26 tahun beserta usia 41 - 45 tahun mempunyai jumlah responden yang sama yaitu sebanyak 15 responden $(16 \%)$. 
Hasil uji validitas dan reliabilitas variabel kinerja terhadap jawaban dari kuesioner adalah sebagai berikut:

Tabel 5

Uji coba validitas dan reliabilitas variabel kinerja

Item-Total Statistics

\begin{tabular}{|l|r|r|r|r|}
\hline & $\begin{array}{r}\text { Scale Mean if Item } \\
\text { Deleted }\end{array}$ & $\begin{array}{r}\text { Scale Variance } \\
\text { if Item Deleted }\end{array}$ & $\begin{array}{c}\text { Cronbach's } \\
\text { Corrected Item- } \\
\text { Total Correlation }\end{array}$ & $\begin{array}{c}\text { Alpha if Item } \\
\text { Deleted }\end{array}$ \\
\hline Skor1 & 175.73 & 724067.926 & 1.000 & .771 \\
Skor2 & 175.69 & 723723.038 & 1.000 & .771 \\
Skor3 & 175.63 & 723209.647 & 1.000 & .771 \\
Skor4 & 175.77 & 724412.179 & 1.000 & .771 \\
Skor5 & 175.90 & 726146.179 & 1.000 & .772 \\
Skor6 & 175.75 & 724239.263 & 1.000 & .771 \\
Skor7 & 175.81 & 724755.122 & 1.000 & .772 \\
Skor8 & 175.58 & 722865.067 & 1.000 & .771 \\
Skor9 & 175.52 & 722352.210 & 1.000 & .771 \\
Skor10 & 175.50 & 722180.189 & 1.000 & .771 \\
Skor11 & 176.00 & 726303.832 & 1.000 & .772 \\
Skor12 & 175.67 & 723903.046 & 1.000 & .771 \\
Skor_Total & 91.71 & 197081.619 & 1.000 & 1.000 \\
\hline
\end{tabular}

Reliability Statistics

\begin{tabular}{|l|l}
\hline Cronbach's Alpha & Nof Items \\
\hline
\end{tabular}

$.790 \quad 13$

Untuk Cronbach's Alpha sebesar 0,790 > 0,6 sehingga set/item pertanyaan yang digunakan sudah reliable.

Hasil uji validitas dan reliabilitas variabel gaya kepemimpinan transaksional terhadap jawaban dari kuesioner adalah sebagai berikut: 
Tabel 6

Uji coba validitas dan reliabilitas variabel gaya kepemimpinan transaksional

Item-Total Statistics

\begin{tabular}{|l|r|r|r|r|}
\hline & $\begin{array}{c}\text { Scale Mean if } \\
\text { Item Deleted }\end{array}$ & $\begin{array}{c}\text { Scale } \\
\text { Variance if } \\
\text { Item Deleted }\end{array}$ & $\begin{array}{c}\text { Corrected } \\
\text { Item-Total } \\
\text { Correlation }\end{array}$ & $\begin{array}{c}\text { Cronbach's } \\
\text { Alpha if Item } \\
\text { Deleted }\end{array}$ \\
\hline Skor1 & 97.35 & 222032.968 & 1.000 & .782 \\
Skor2 & 97.44 & 222511.680 & 1.000 & .782 \\
Skor3 & 97.27 & 221750.115 & 1.000 & .782 \\
Skor4 & 97.44 & 222511.659 & 1.000 & .782 \\
Skor5 & 97.38 & 222420.595 & 1.000 & .782 \\
Skor6 & 97.38 & 222322.700 & 1.000 & .782 \\
Skor7 & 97.54 & 222988.925 & 1.000 & .783 \\
Skor8 & 97.29 & 221845.282 & 1.000 & .782 \\
Skor_Total & 51.92 & 63232.414 & 1.000 & 1.000 \\
\hline
\end{tabular}

Reliability Statistics

\begin{tabular}{|r|r|}
\hline Cronbach's Alpha & N of Items \\
\hline .809 & 9 \\
\hline
\end{tabular}

Untuk Cronbach's Alpha sebesar 0,809 > 0,6 sehingga set/item pertanyaan yang digunakan sudah reliable.

Hasil uji validitas dan reliabilitas variabel gaya kepemimpinan transformasional terhadap jawaban dari kuesioner adalah sebagai berikut: 
Tabel 7

Uji coba validitas dan reliabilitas variabel gaya kepemimpinan transformasional

Item-Total Statistics

\begin{tabular}{|l|r|r|r|r|}
\hline & $\begin{array}{c}\text { Scale Mean if } \\
\text { Item Deleted }\end{array}$ & $\begin{array}{c}\text { Scale } \\
\text { Variance if } \\
\text { Item Deleted }\end{array}$ & $\begin{array}{c}\text { Corrected } \\
\text { Item-Total } \\
\text { Correlation }\end{array}$ & $\begin{array}{c}\text { Cronbach's } \\
\text { Alpha if Item } \\
\text { Deleted }\end{array}$ \\
\hline Skor1 & 99.08 & 230698.414 & 1.000 & .783 \\
Skor2 & 98.98 & 230212.736 & 1.000 & .783 \\
Skor3 & 98.58 & 228374.498 & 1.000 & .781 \\
Skor4 & 98.73 & 229050.705 & 1.000 & .781 \\
Skor5 & 98.73 & 229050.831 & 1.000 & .781 \\
Skor6 & 98.90 & 229825.757 & 1.000 & .782 \\
Skor7 & 98.88 & 229729.079 & 1.000 & .782 \\
Skor8 & 99.06 & 230600.986 & 1.000 & .783 \\
Skor_Total & 52.73 & 65334.621 & 1.000 & 1.000 \\
\hline
\end{tabular}

Reliability Statistics

\begin{tabular}{|r|r|}
\hline Cronbach's Alpha & N of Items \\
\hline .809 & 9 \\
\hline
\end{tabular}

Untuk Cronbach's Alpha sebesar 0,809>0,6 sehingga set/item pertanyaan yang digunakan sudah reliable.

Hasil uji validitas dan reliabilitas variabel motivasi terhadap jawaban dari kuesioner adalah sebagai berikut: 
Tabel 8

Uji coba validitas dan reliabilitas variabel motivasi

\section{Item-Total Statistics}

\begin{tabular}{|l|r|r|r|r|}
\hline & $\begin{array}{c}\text { Scale Mean if } \\
\text { Item Deleted }\end{array}$ & $\begin{array}{c}\text { Scale } \\
\text { Variance if } \\
\text { Item Deleted }\end{array}$ & $\begin{array}{c}\text { Corrected } \\
\text { Item-Total } \\
\text { Correlation }\end{array}$ & $\begin{array}{c}\text { Cronbach's } \\
\text { Alpha if Item } \\
\text { Deleted }\end{array}$ \\
\hline Skor1 & 70.96 & 118319.135 & 1.000 & .794 \\
Skor2 & 71.00 & 118458.442 & 1.000 & .794 \\
Skor3 & 70.75 & 117624.968 & 1.000 & .792 \\
Skor4 & 70.81 & 117833.122 & 1.000 & .792 \\
Skor5 & 71.17 & 119014.646 & 1.000 & .795 \\
Skor6 & 70.88 & 118041.711 & 1.000 & .793 \\
Skor_Total & 38.69 & 35171.291 & 1.000 & 1.000 \\
\hline
\end{tabular}

Reliability Statistics

\begin{tabular}{|r|r|}
\hline Cronbach's Alpha & Nof Items \\
\hline .826 & 7 \\
\hline
\end{tabular}

Untuk Cronbach's Alpha sebesar 0,826 > 0,6 sehingga set/item pertanyaan yang digunakan sudah reliable.

Hasil uji validitas dan reliabilitas variabel kompetensi terhadap jawaban dari kuesioner adalah sebagai berikut: 
Tabel 9

Uji coba validitas dan reliabilitas variabel kompetensi

\section{Item-Total Statistics}

\begin{tabular}{|l|r|r|r|r|}
\hline & $\begin{array}{c}\text { Scale Mean if } \\
\text { Item Deleted }\end{array}$ & $\begin{array}{c}\text { Scale } \\
\text { Variance if } \\
\text { Item Deleted }\end{array}$ & $\begin{array}{c}\text { Corrected } \\
\text { Item-Total } \\
\text { Correlation }\end{array}$ & $\begin{array}{c}\text { Cronbach's } \\
\text { Alpha if Item } \\
\text { Deleted }\end{array}$ \\
\hline Skor1 & 94.83 & 211329.467 & 1.000 & .784 \\
Skor2 & 94.46 & 209662.082 & 1.000 & .782 \\
Skor3 & 94.56 & 210124.880 & 1.000 & .782 \\
Skor4 & 94.56 & 210124.564 & 1.000 & .782 \\
Skor5 & 94.40 & 209385.273 & 1.000 & .781 \\
Skor6 & 94.50 & 209847.032 & 1.000 & .782 \\
Skor7 & 94.40 & 209384.957 & 1.000 & .781 \\
Skor8 & 94.85 & 211423.768 & 1.000 & .784 \\
Skor_Total & 50.44 & 59778.649 & 1.000 & 1.000 \\
\hline
\end{tabular}

Reliability Statistics

\begin{tabular}{|r|r|}
\hline Cronbach's Alpha & N of Items \\
\hline .809 & 9 \\
\hline
\end{tabular}

Untuk Cronbach's Alpha sebesar 0,809 > 0,6 sehingga set/item pertanyaan yang digunakan sudah reliable.

\section{PEMBAHASAN}

Dalam penelitian ini yang melibatkan 95 orang responden, memberikan informasi mengenai pengaruh dari variabel gaya kepemimpinan transaksional dan transformasional, motivasi serta kompetensi terhadap kinerja karyawan PT. 
Sanjayatama Lestari, maka selanjutnya perlu dibahas eksistensi masing-masing variabel sebagai berikut:

1. Pengaruh Gaya Kepemimpinan Transaksional Terhadap Kinerja Karyawan PT. Sanjayatama Lestari

Dari hasil penelitian yang dilakukan terbukti bahwa terdapat pengaruh positif antara gaya kepemimpinan transaksional terhadap kinerja karyawan PT. Sanjayatama Lestari. Dari perhitungan SPSS 16.0 T hitung yang diperoleh sebesar 3,876 dan T tabel sebesar 1,986. Dengan demikian T hitung > T tabel, sehingga hal ini menunjukkan bahwa variabel gaya kepemimpinan transaksional $\left(\mathrm{X}_{1}\right)$ mempunyai hubungan linear dan signifikan terhadap kinerja karyawan PT. Sanjayatama Lestari.

Dari delapan indikator yang ada, indikator menegur karyawan yang menyimpang aturan dipersepsikan paling tinggi oleh responden dengan bobot yaitu sebesar 3,34. Sehingga gaya kepemimpinan transaksional pada PT. Sanjayatama Lestari dominan dengan menegur karyawan yang menyimpang aturan.

Semakin tepat penerapan gaya kepemimpinan transaksional, maka hal tersebut dapat menyebabkan kinerja karyawan PT. Sanjayatama Lestari menjadi meningkat. Gaya kepemimpinan transaksional adalah pemimpin yang menekankan pada tugas yang diembannya. Dengan diterapkannya gaya kepemimpinan transaksional yang tepat maka dapat menciptakan integrasi yang serasi dan mendorong kinerja karyawan untuk mencapai tujuan yang ditetapkan oleh pimpinan.

Hasil penelitian ini ternyata sesuai dengan teori-teori yang peneliti kemukakan sebelumnya dan juga sama dengan hasil penelitian yang relevan sebelumnya, seperti penelitian Martha Andy Pradana. Hasil penelitiannya menyimpulkan bahwa variabel gaya kepemimpinan transaksional memiliki pengaruh signifikan terhadap kinerja karyawan. Dengan kata lain penelitian 
yang dilakukan oleh peneliti juga memberikan kesimpulan yang sama dengan penelitian sebelumnya.

2. Pengaruh Gaya Kepemimpinan Transformasional Terhadap Kinerja Karyawan PT. Sanjayatama Lestari

Dari hasil penelitian, terbukti bahwa terdapat pengaruh antara gaya kepemimpinan transformasional terhadap kinerja karyawan. Hal ini terlihat dari nilai $\mathrm{T}$ hitung yang diperoleh sebesar 3,128 dan $\mathrm{T}$ tabel sebesar 1,986. Oleh karena perhitungan tersebut maka $\mathrm{T}$ hitung $>\mathrm{T}$ tabel, sehingga variabel gaya kepemimpinan transformasional mempunyai hubungan linear dan signifikan terhadap kinerja karyawan PT. Sanjayatama Lestari.

Dari delapan indikator yang ada, indikator optimis untuk mencapai target suatu pekerjaan dipersepsikan paling tinggi oleh responden dengan bobot yaitu sebesar 3,47. Sehingga gaya kepemimpinan transformasional pada PT. Sanjayatama Lestari dominan dengan sikap optimis untuk mencapai target pekerjaan di PT. Sanjayatama Lestari.

Semakin tepat penerapan gaya kepemimpinan transformasional, maka hal tersebut dapat menyebabkan kinerja karyawan PT. Sanjayatama Lestari menjadi meningkat. Gaya kepemimpinan transformasional adalah pemimpin yang memberikan perhatian kepada pengikutnya. Dengan diterapkannya gaya kepemimpinan transformasional yang tepat maka dapat menciptakan integrasi yang serasi antara pimpinan dan bawahan, mendorong semangat dan kinerja karyawan untuk mencapai tujuan yang telah ditetapkan oleh pimpinan.

Hasil penelitian ini ternyata sesuai dengan teori-teori yang peneliti kemukakan sebelumnya dan juga sama dengan hasil penelitian yang relevan sebelumnya, seperti penelitian Friskha Dora Simanjuntak dan Ahmad Calam. Hasil penelitiannya menyimpulkan bahwa variabel gaya kepemimpinan transformasional memberikan dorongan positif bagi bawahan, sehingga bawahan tersebut termotivasi untuk melakukan lebih dari yang diharapkan dan 
berpengaruh terhadap peningkatan kinerja. Dengan kata lain penelitian yang dilakukan oleh peneliti juga memberikan kesimpulan yang sama dengan penelitian sebelumnya.

3. Pengaruh Motivasi Terhadap Kinerja Karyawan PT. Sanjayatama Lestari

T hitung motivasi $\left(\mathrm{X}_{3}\right)$ yang diperoleh sebesar 4,210 dan $\mathrm{T}$ tabel sebesar 1,986. Oleh karena perhitungan tersebut maka $\mathrm{T}$ hitung $>\mathrm{T}$ tabel, sehingga motivasi mempunyai hubungan yang linear dan signifikan terhadap kinerja karyawan PT. Sanjayatama Lestari. Diharapkan motivasi yang diberikan dapat terus ditingkatkan, sehingga motivasi yang diberikan dapat juga meningkatkan kinerja karyawan PT. Sanjayatama Lestari untuk menjadi lebih baik lagi.

Dari enam indikator yang ada, indikator keamanan dan keselamatan merupakan hal yang dinilai paling tinggi oleh responden dengan bobot yaitu sebesar 3,34. Sehingga motivasi pada PT. Sanjayatama Lestari dominan dengan adanya kepastian mengenai keamanan dan keselamatan kerja bagi para karyawan untuk bekerja di PT. Sanjayatama Lestari.

Semakin tepat penerapan motivasi, maka hal tersebut dapat menyebabkan kinerja karyawan PT. Sanjayatama Lestari menjadi meningkat. Motivasi adalah suatu keinginan dan mempunyai tujuan yang ingin dicapai. Dengan diterapkannya motivasi yang tepat maka dapat menumbuhkan dan menciptakan semangat karyawan untuk bekerja dan mencapai tujuan organisasi.

Hasil penelitian ini ternyata sesuai dengan teori-teori yang peneliti kemukakan sebelumnya dan juga sama dengan hasil penelitian yang relevan sebelumnya, seperti penelitian Linawati. Teknik analisis data kuantitatif menggunakan uji validitas, uji reliabilitas, uji asumsi klasik dan uji hipotesis. Hasil penelitiannya menyimpulkan bahwa variabel motivasi mempunyai pengaruh yang penting terhadap kinerja karyawan. Dengan kata lain penelitian 
yang dilakukan oleh peneliti juga memberikan kesimpulan yang sama dengan penelitian sebelumnya.

4. Pengaruh Kompetensi Terhadap Kinerja Karyawan PT. Sanjayatama Lestari

$\mathrm{T}$ hitung kompetensi $\left(\mathrm{X}_{4}\right)$ sebesar 6,823 dan $\mathrm{T}$ tabel sebesar 1,986. $\mathrm{T}$ hitung yang diperoleh $>\mathrm{T}$ tabel maka dapat disimpulkan bahwa H0 ditolak dan $\mathrm{H} 1$ diterima, yang artinya bahwa terdapat hubungan linear antara kompetensi terhadap kinerja karyawan PT. Sanjayatama Lestari. Diharapkan kompetensi dapat terus meningkatkan kinerja karyawan PT. Sanjayatama Lestari sehingga karyawan dapat terus bekerja secara optimal demi kemajuan bersama.

Dari empat indikator yang ada, indikator penguasaan teknologi merupakan hal yang dinilai paling tinggi oleh responden dengan bobot yaitu sebesar 3,25. Sehingga kompetensi pada PT. Sanjayatama Lestari dominan dengan adanya karyawan yang menguasai teknologi di PT. Sanjayatama Lestari.

Semakin tepat penerapan kompetensi, maka hal tersebut dapat menyebabkan kinerja karyawan PT. Sanjayatama Lestari menjadi meningkat. Kompetensi adalah pengetahuan, keahlian dan sifat yang dimiliki untuk menghasilkan kinerja yang unggul. Dengan diterapkannya kompetensi yang tepat maka dapat mengubah cara bekerja karyawan yaitu dari cara kerja yang manual menjadi automatically. Kecepatan dan ketepatan dalam bekerja pun dapat terlihat dengan jelas karena adanya teknologi-teknologi yang diberikan bagi kemudahan karyawan saat bekerja.

Hasil penelitian ini ternyata sesuai dengan teori-teori yang peneliti kemukakan sebelumnya dan juga sama dengan hasil penelitian yang relevan sebelumnya, seperti penelitian Ronald Listio. Teknik analisis menggunakan dua jenis analisis yaitu analisis deskriptif dan analisis kuantitatif. Hasil penelitiannya menyimpulkan bahwa variabel kompetensi mempunyai pengaruh terhadap kinerja karyawan. Hal ini berarti kompetensi mempunyai 
peran untuk meningkatkan kinerja karyawan PT. Aliannz Life Indonesia Wilayah Jawa Barat. Dengan kata lain penelitian yang dilakukan oleh peneliti juga memberikan kesimpulan yang sama dengan penelitian sebelumnya.

\section{KESIMPULAN}

Berdasarkan hasil pengolahan dan analisis terhadap keseluruhan data yang diteliti, kesimpulan yang dapat diperoleh adalah sebagai berikut:

1. Berdasarkan hasil analisis, variabel gaya kepemimpinan transaksional mempunyai pengaruh yang positif dan signifikan terhadap kinerja karyawan. Hal ini terlihat pada beberapa indikator, seperti pemberian imbalan melalui bonus karyawan yang diberikan sesuai dengan pencapaian target perusahaan dan memarahi karyawan jika ada karyawan yang menyimpang aturan perusahaan. Kesimpulan ini juga didukung oleh penelitian sebelumnya yaitu penelitian Martha Andy Pradana yang menyimpulkan bahwa variabel gaya kepemimpinan transaksional memiliki pengaruh signifikan terhadap kinerja karyawan.

2. Berdasarkan hasil analisis, variabel gaya kepemimpinan transformasional mempunyai pengaruh yang positif dan signifikan terhadap kinerja karyawan. Hal ini terlihat pada beberapa indikator, seperti partisipasi karyawan terhadap semua kegiatan produk-produk Unilever, karyawan mau mengikuti pelatihan yang diberikan oleh PT. Sanjayatama Lestari yang tujuannya untuk meningkatkan keahlian para karyawan dan juga pemberian sikap optimis agar karyawan dapat mencapai target perusahaan. Kesimpulan ini juga didukung oleh penelitian sebelumnya yaitu penelitian Friskha Dora Simanjuntak, Ahmad Calam, Roy Johan Agung Tucunan, Wayan Gede Supartha dan I Gede Riana yang menyimpulkan bahwa variabel gaya kepemimpinan transformasional memiliki pengaruh yang positif dan signifikan terhadap kinerja karyawan. 
3. Berdasarkan hasil analisis, variabel motivasi mempunyai pengaruh yang positif dan signifikan terhadap kinerja karyawan. Hal ini terlihat pada beberapa indikator, seperti gaji karyawan yang dinilai cukup untuk memenuhi kebutuhan pokok karyawan, jenjang karir yang diberikan oleh PT. Sanjayatama Lestari dianggap mampu memotivasi para karyawan untuk bekerja sebaik mungkin sehingga karyawan mampu mencapai target yang diberikan oleh perusahaan dan juga keamanan dan keselamatan para karyawan saat bekerja di PT. Sanjayatama Lestari yang mampu memberikan kondisi kerja yang aman, nyaman dan tenang. Kesimpulan ini juga didukung oleh penelitian sebelumnya yaitu penelitian Linawati, Agus Pramono, Dian Triyani, Bayu Saptianingsih, Komang Anik Yuliaarnita, Nicko Permana Putra dan Kristina Nugi Keran yang menyimpulkan bahwa variabel motivasi memiliki pengaruh yang positif dan signifikan terhadap kinerja karyawan.

4. Berdasarkan hasil analisis, variabel kompetensi mempunyai pengaruh yang positif dan signifikan terhadap kinerja karyawan. Hal ini terlihat pada beberapa indikator, seperti karyawan mampu menguasai bidang tugasnya, terampil dan ahli dalam penguasaan teknologi yang fungsinya untuk membantu karyawan agar menyelesaikan pekerjaannya secara cepat dan akurat berdasarkan data yang ada di PT. Sanjayatama Lestari. Kesimpulan ini juga didukung oleh penelitian sebelumnya yaitu penelitian Gusti Ayu Riska Riyanti, I Gede Adnyana Sudibya, I Kadek Edy Sanjaya, Ayu Desi Indrawati dan Ronald Listio yang menyimpulkan bahwa variabel kompetensi memiliki pengaruh yang positif dan signifikan terhadap kinerja karyawan. 


\section{DAFTAR PUSTAKA}

Ainsworth, Murray, Managing Performance, Managing People: Understanding and Improving Team Performance, Frenchs Forest: Pearson Education, 2002.

Bass, Bernard M. \& Ronald E. Riggio, Transformational Leadership, The United States of America: Lawrence Erlbaum Associates Inc, 2006.

Eko, Suparno, Manajemen Pengembangan Sumber Daya Manusia, Jakarta: Ardadizya Jaya, 2014.

Ferdinand, Augustynd, Metode Penelitian Manajemen, Semarang: AGF Books, 2006.

Hollyforde \& Whiddett, The Motivation Handbook, Mumbai: Jaico Publishing House, 2003.

K. Hoy, Wayne \& Cecil G. Miskel, Educational Administration Theory, Research and Practice, New York: Mc Graw Hill, 2005.

Keran, Kristina Nugi, Pengaruh Motivasi Kerja, Kompetensi Dan Kompensasi Terhadap Kinerja Karyawan di Yayasan Bintang Timur Tanggerang, Universitas Esa Unggul, 2012.

Khozin, Hierarki Kebutuhan Maslow Dalam Perspektif Pendidikan Islam, Yogyakarta: Interpena, 2012.

Kippenberger, Tony, Leadership Styles, United Kingdom: Capstone Publishing, 2002.

Kondalkar V.G., Organizational Behavior, New Delhi: New Age International Limited Publishers, 2007.

Listio, Ronald, Pengaruh Kompetensi Dan Motivasi Kerja Terhadap Kinerja Karyawan PT. Aliannz Life Indonesia Wilayah Jawa Barat, Universitas Komputer Indonesia Bandung, 2010.

Linawati, Pengaruh Motivasi, Kompetensi, Kepemimpinan Dan Lingkungan Kerja Terhadap Kinerja Karyawan (Studi Pada PT. Herculon Carpet Semarang), Sekolah Tinggi Ilmu Ekonomi Widya Manggala, 2011. 
Luthan, Fred, Organizational Behavior: An Evidence-Based Approach, New York: McGraw-Hill, 2011.

Mangkunegara, Anwar Prabu, Manajemen Sumber Daya Manusia Perusahaan, Bandung: Remaja Rosdakarya, 2001.

Mulyasa, E., Manajemen Berbasis Sekolah Konsep, Strategi dan Implementasi, Bandung: PT. Remaja Rosdakarya Offset, 2011.

Nahavandi, Afsaneh, The Art And Science Of Leadership, New Jersey: Prentice Hall Inc, 2000.

Noe, A Raymond, Manajemen Sumber Daya Manusia Mencapai Keunggulan Bersaing, Jakarta: Salemba Empat, 2013.

Pradana, Martha Andy, Pengaruh Gaya Kepemimpinan Transformasional Dan Transaksional Terhadap Kinerja Karyawan (Studi Pada Karyawan Tetap PT. Mustika Bahana Jaya, Lumajang), Pradana Vol. 4 no. 1, 2013.

Pramono, Agus, Dian Triyani. Pengaruh Kompensasi, Motivasi, Lingkungan Kerja Dan Kepemimpinan Terhadap Kinerja Karyawan PT. Adi Mitra Pratama Semarang, Jurnal dinamika volume 1 nomor 5, 2010.

Putra, Nicko Permana, Pengaruh Kepemimpinan, Motivasi, Lingkungan Kerja Dan Disiplin Kerja Terhadap Kinerja Karyawan Pada PT. Indonesia Power Semarang, Jurnal Indonesia Power Semarang, 2013.

Riyanti Gusti Ayu Riska, I Gede Adnyana Sudibya, Pengaruh Motivasi Dan Kompetensi Terhadap Kinerja Karyawan Pada RSU Dharma Usadha, (Fakultas Ekonomi Universitas Udayana, 2012), h. 622.

Rosadi, Dodi, Pengaruh Kompensasi Dan Lingkungan Kerja Terhadap Motivasi Kerja Serta Dampaknya Pada Kinerja Pegawai di Pusat Pembinaan, Pendidikan Dan Pelatihan Peneliti-LIPI, Pusat Pembinaan, Pendidikan Dan Pelatihan Peneliti-LIPI, 2015.

Sanjaya, I Kadek Edy, Ayu Desi Indrawati. Pengaruh Kompetensi, Kompensasi Dan Lingkungan Kerja Terhadap Kinerja Karyawan Pada PT. Pande Agung Segara Dewata, Fakultas Ekonomi Universitas Udayana, 2013.

Sanjaya, Wina, Strategi Pembelajaran Berorientasi Standar Proses Pendidikan, Jakarta: Kencana Prenadamedia Group, 2013.

Santoso, Singgih, Menggunakan SPSS Untuk Statistik Parametrik, Jakarta: Alex Media Komputindo, 2006. 
Saptianingsih, Bayu, Pengaruh Kompensasi, Motivasi Dan Lingkungan Kerja Terhadap Kinerja Karyawan Bagian Produksi PT. Nyonya Meneer Semarang, lib.unnes.ac.id, 2010.

Sekaran, Uma, Research Methods For Business, Jakarta: Salemba Empat, 2006.

Simanjuntak Friskha Dora, Ahmad Calam. Pengaruh Kepemimpinan Transformasional Dan Motivasi Kerja Terhadap Kinerja Karyawan PT. PLN (PERSERO) Cabang Binjai Wilayah Sumatera Utara, Jurnal SAINTIKOM Vol. 11 No.2, 2012.

Sudaryono, Leadership: Teori Dan Praktek Kepemimpinan, Jakarta Pusat: Lentera Ilmu Cendekia, 2014.

Sugiyono. Metode Penelitian Administrasi, Bandung: Alfabeta, 2002.

Sugiyono. Metode Penelitian Bisnis Pendekatan Kuantitatif, Kualitatif dan R\&D, Bandung: Alfabeta CV, 2009.

Suharsaputra, Uhar. Administrasi Pendidikan, Bandung: PT. Refika Aditama, 2013.

Sunyoto, Danang, Manajemen Sumber Daya Manusia, Jakarta: CAPS, 2013.

Tim Program Pascasarjana. Buku Pedoman Penulisan Tesis Dan Disertasi, Jakarta: Pascasarjana, 2012.

Tim Redaksi, Leadership and Management in Organizations, London: Elsevier, 2007.

Tucunan, Roy Johan Agung, Wayan Gede Supartha dan I Gede Riana. Pengaruh Kepemimpinan Transformasional Terhadap Motivasi Dan Kinerja Karyawan (Studi Kasus Pada PT. Pandawa), E-Jurnal Ekonomi dan Bisnis Universitas Udayana 3.9, 2014.

Yuliaarnita, Komang Anik, Pengaruh Gaya Kepemimpinan Transformasional Dan Motivasi Terhadap Kinerja Karyawan Pada PT. Sorga Indah Handicrafts, Telkom University, 2014.

Yukl, Gary, Kepemimpinan Dalam Organisasi Edisi Kelima, Jakarta: PT. Indeks, 2005.

Yukl, Gary, Leadership in Organizations Seventh Edition, United States of America: Pearson Prentice Hall, 2010. 